\title{
Nickel Uptake by Cypress Pine (Callitris glaucophylla) in the Miandetta Area, Australia: Implications for Use in Biogeochemical Exploration
}

\author{
Kenneth G. McQueen ${ }^{1, * \mathbb{D}}$, Augustine Alorbi ${ }^{2}$, Joseph A. Schifano ${ }^{3,4}$ and David R. Cohen ${ }^{3,4}$ \\ 1 Faculty of Science and Technology, University of Canberra, Canberra, ACT 2601, Australia \\ 2 MMG Ltd., Sydney, NSW 2001, Australia; aalorbi@gmail.com \\ 3 School of Biological, Earth and Environmental Sciences, University of New South Wales, \\ Sydney, NSW 2052, Australia; j.schifano@unsw.edu.au (J.A.S.); d.cohen@unsw.edu.au (D.R.C.) \\ 4 Mineral Exploration Cooperative Research, Kensington, WA 6151, Australia \\ * Correspondence: ken.mcqueen@canberra.edu.au
}

check for

updates

Citation: McQueen, K.G.; Alorbi, A.; Schifano, J.A.; Cohen, D.R. Nickel Uptake by Cypress Pine (Callitris glaucophylla) in the Miandetta Area, Australia: Implications for Use in Biogeochemical Exploration. Minerals 2021, 11, 808. https://doi.org/ $10.3390 / \min 11080808$

Academic Editors: Walid Salama, Caroline Tiddy and Ryan Noble

Received: 21 May 2021

Accepted: 23 July 2021

Published: 26 July 2021

Publisher's Note: MDPI stays neutral with regard to jurisdictional claims in published maps and institutional affiliations.

Copyright: (c) 2021 by the authors. Licensee MDPI, Basel, Switzerland. This article is an open access article distributed under the terms and conditions of the Creative Commons Attribution (CC BY) license (https:/ / creativecommons.org/licenses/by/ $4.0 /)$.

\begin{abstract}
The uptake of $\mathrm{Ni}$ and other elements by Callitris glaucophylla (white cypress pine), from weathered ultramafic rocks under varying depths of transported regolith cover, is examined at two sites in the Miandetta area, New South Wales, Australia. Results show that C. glaucophylla can accumulate elevated $\mathrm{Ni}$ concentrations in the needles (leaves or phyllodes) from underlying Ni-enriched regolith up to two orders of magnitude above the normal micronutrient levels required for the species. Such uptake levels occur in areas with high total $\mathrm{Ni}$ in the soil and regolith despite the relatively low mobility of the Ni due to its presence in a low availability form. This highlights the importance of biotic processes in extracting $\mathrm{Ni}$ from soil. The needles of C. glaucophylla could provide an effective and convenient sampling medium for reconnaissance biogeochemical exploration for $\mathrm{Ni}$ mineralisation and anomalies where transported regolith is less than $\sim 3 \mathrm{~m}$ thick. The study has also demonstrated the potential for in situ analysis of $\mathrm{Ni}$ and other elements in the needles by portable XRF.
\end{abstract}

Keywords: biogeochemistry; mineral exploration; pXRF; Cobar region; in situ and transported regolith

\section{Introduction}

Over the last twenty years, there has been resurgent interest in biogeochemical exploration methods, particularly for potential application in the vast regolith-dominated areas of Australia [1-5]. This interest has also been linked to advances in analytical methods for plant materials. Numerous case studies have documented the uptake of elements by various plant species and assessment of approaches to sampling and chemical analysis to detect geochemical dispersion patterns linked to underlying mineralisation within residual and transported regolith [6,7]. However, there is limited quantitative information on the controls on element uptake from regolith including the maximum depth from which plant roots can effectively acquire elements from weathered bedrock through transported regolith cover.

Callitris glaucophylla (white cypress pine) is native to Australia and widespread in semi-arid parts of western New South Wales, southern Queensland and, to a lesser extent, in southern Western Australia and South Australia (Figure 1) [8]. The species is tolerant of a range of soil types and is common on well-drained sandy soils as well as rocky, skeletal soils [9]. Phenological studies of C. glaucophylla indicate very little growth occurs in winter months and that it is dependent on prevailing conditions at other times [10]. A large proportion of the fine roots are restricted to the top $2.5 \mathrm{~m}$ of the soil, with most occurring in the top $0.5 \mathrm{~m} \mathrm{[11]}$. Feeder roots have been observed extending laterally for up to 6 $\mathrm{m}$, generally along the interface between the upper soil and the underlying, moisture- 
retaining clay-rich horizon $[9,12]$. The depth of penetration of feeder roots or the existence of significant tap roots has not been documented.

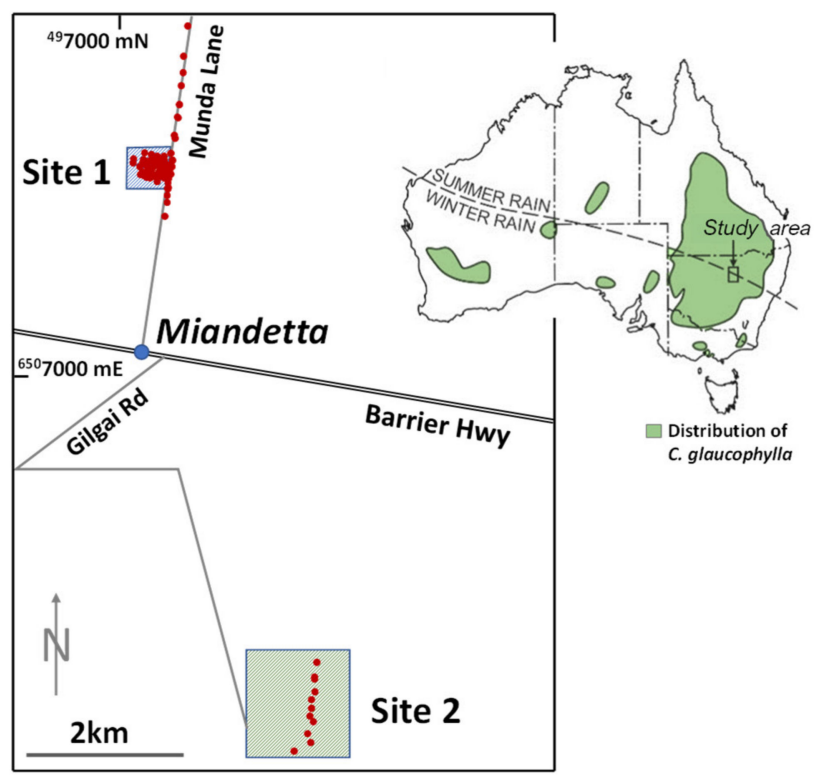

Figure 1. Location of the two study sites near Miandetta and positions of sampled trees. Insert map shows the approximate distribution of white cypress pine (Callitris glaucophylla) in Australia [8] and regional location of the study sites in north-west New South Wales.

There is a lack of biogeochemical studies on the Callitris genus. Previous biogeochemical studies at two mineralised sites in the Cobar area west of Miandetta indicate C. glaucophylla needles can display anomalous concentrations of $\mathrm{Au}, \mathrm{As}, \mathrm{Sb}, \mathrm{Ba}$ and $\mathrm{La}$ in the vicinity of mineralisation where regolith cover is thin $(<5 \mathrm{~m})$ [13]. At the McKinnons Au deposit, multi-element anomalies detected in needles were found in trees up to $1 \mathrm{~km}$ either side of sub-cropping Au mineralisation, with up to $4.2 \mu \mathrm{g} / \mathrm{kg} \mathrm{Au}$ (background $0.8 \mu \mathrm{g} / \mathrm{kg}$ ), $0.4 \mathrm{mg} / \mathrm{kg}$ As (background $0.05 \mathrm{mg} / \mathrm{kg}$ ) and $0.4 \mathrm{mg} / \mathrm{kg} \mathrm{Sb}$ (background $0.05 \mathrm{mg} / \mathrm{kg}$ ). A regional biogeochemical survey of the Cobar Basin and detailed mapping of C. glaucophylla chemistry over a range of mineral deposits is currently underway.

This study documents the uptake of $\mathrm{Ni}$ and other elements by C. glaucophylla through different residual and transported regolith depths overlying weathered ultramafic units at two sites near Miandetta, $20 \mathrm{~km}$ west of Nyngan in north-west New South Wales (Figure 1). The key objectives are to further assess the suitability and limits of this widespread species of tree as a sampling medium in mineral exploration in regolith-dominated terrains in Australia and the application of portable X-ray fluorescence spectrometry (pXRF) analysis in the field.

\section{Site Descriptions}

The area around Miandetta contains several mafic-ultramafic bodies with elevated $\mathrm{Ni}(1500-3000 \mathrm{mg} / \mathrm{kg}$ ) and other ultramafic-associated transition metals, surrounded by meta-sedimentary and meta-volcanic rocks of the Ordovician Girilambone Group. At the two sites examined, previous drilling for lateritic Ni, PGE, Au and Sc mineralisation provided information on the depth and composition of the regolith, including transported material, the weathered saprolite and underlying parent rock.

Site 1 surrounds an old ballast quarry ( $\sim 5 \mathrm{~m}$ deep) $2.4 \mathrm{~km}$ north of Miandetta along Munda Lane (Figure 2). The small area around the quarry has a remnant open forest with mature cypress pines and is surrounded by cleared paddocks. There is a windbreak of cypress pine and eucalypts extending along the edge of Munda Lane. The bedrock is a folded and faulted, partly silicified serpentinite which has undergone deep chemical 
weathering. Northwest trending quartz veins are developed in the serpentinite body. The subsurface position of this body is indicated in the regional total magnetic intensity (TMI) map. The TMI also indicates increased cover to the west and north (Figure 2). Near the quarry, the regolith cover is $<2 \mathrm{~m}$. A ferruginous 'lateritic' cap at least $3 \mathrm{~m}$ thick is exposed in the quarry and crops out locally. To the north and west of the central area, there is a thicker layer of regolith (to $\sim 5 \mathrm{~m}$ depth) with both residual and transported components and lower TMI. There are also some small outcrops of silcreted gravels representing cemented alluvial remnants of overlying channels, now largely eroded away.

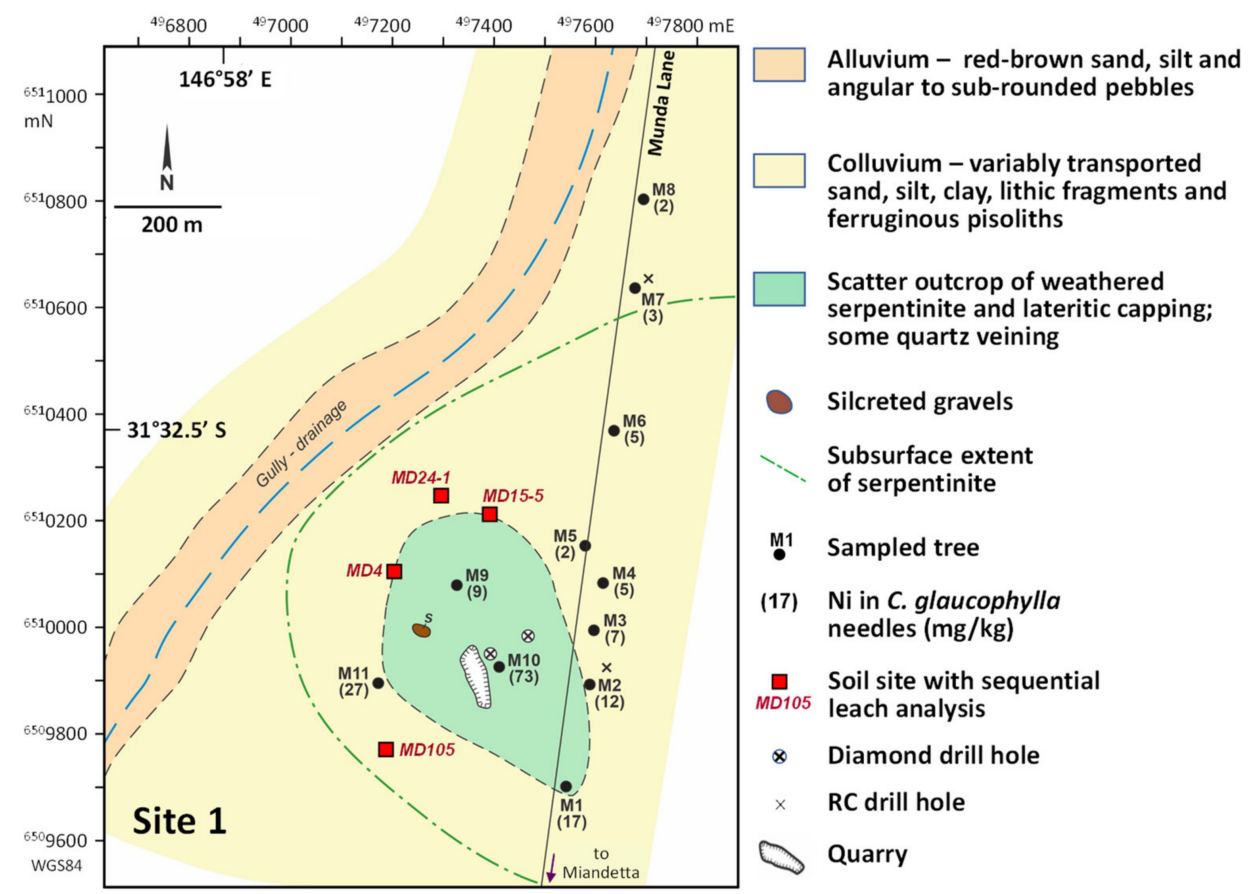

Figure 2. Map of Site 1 showing locations of $C$. glaucophylla trees sampled in the first round of sampling, the Ni content of their needles and surface geology. Also shown are the locations of two percussion and two diamond drill holes referred to in the text.

A series of RC percussion holes were drilled along the side of Munda Lane by Anaconda Nickel Ltd. during exploration for lateritic Ni mineralisation in 2001, and two of these drill holes are close to the main sampling area. A soil geochemical survey over the area in 2004 revealed a distinct $\mathrm{Ni}$ anomaly $(250-1400 \mathrm{mg} / \mathrm{kg}$ ) with associated $\mathrm{Cu}$ (up to $227 \mathrm{mg} / \mathrm{kg}$ ) and $\mathrm{Au}$ (up to $60 \mu \mathrm{g} / \mathrm{kg}$ ). Twenty shallow $(<20 \mathrm{~m}$ ) percussion holes were also drilled across the weathered serpentinite body by Jervois Mining in 2005 as part of an assessment for gold mineralisation in the area [14]. In 2017, Alpine Meadows Clear-Fill Pty Ltd. drilled two diamond drill holes east of the quarry. The drilling and information from a related soil sampling program provide an extensive knowledge of the geology and geochemistry of the bedrock and regolith at the site [15].

Site 2 is located $4 \mathrm{~km}$ southeast of Miandetta in an area of extensive transported alluvial cover that ranges in thickness from 9 to $>50 \mathrm{~m}$ (Figure 3). The area has been cleared for wheat farming, but there is a $50 \mathrm{~m}$ wide windbreak of cypress pine trees across the fields. The site has been extensively drilled to an underlying 'lateritic' weathering profile on a pyroxenite intrusion during exploration for PGE and Sc mineralisation [16]. The drilling provides information on the thickness of the transported alluvium and the underlying saprolite, as well as the composition and geochemical characteristics of the different materials (Figure 4). The near surface alluvium is composed of brown sand, silt and clay with scattered, transported clasts of metasedimentary rocks and quartz. Deeper in the profile, there are layers containing sub-rounded gravel, particularly close to the unconformity with the underlying weathering profile. 


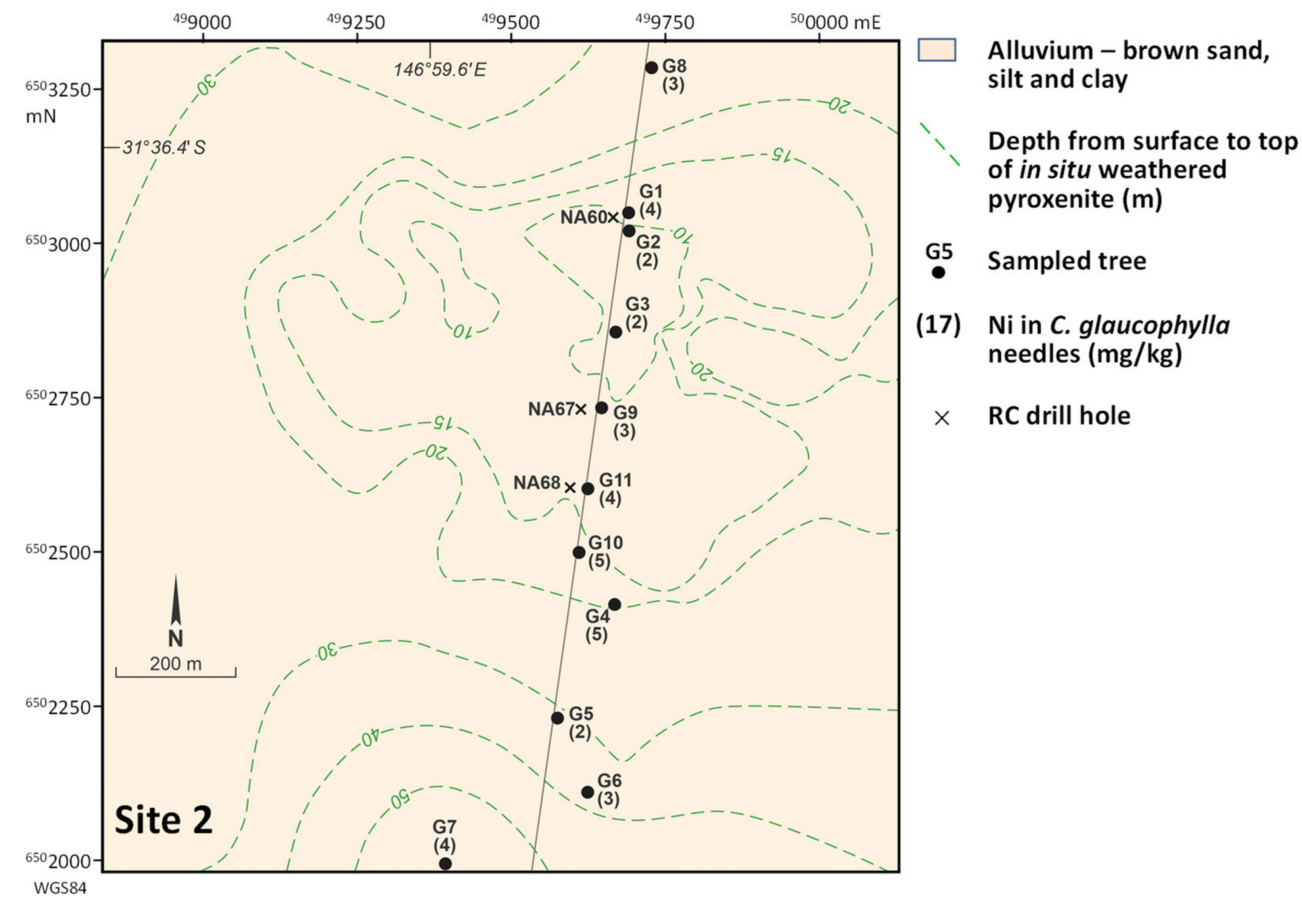

Figure 3. Map of Site 2 showing the location of sampled C. glaucophylla trees, Ni content of needles, surficial geology and the thickness of the transported cover determined by extensive drilling. Also shown are the locations of three percussion drill holes (NA60, NA67, NA68), logged and sampled in detail.

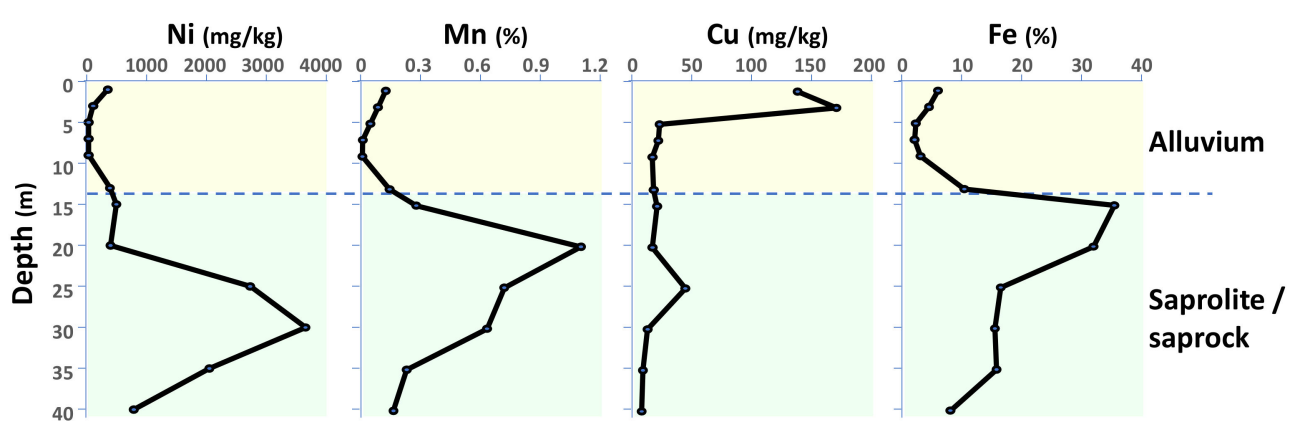

Figure 4. Geochemical profiles showing $\mathrm{Ni}, \mathrm{Mn}, \mathrm{Cu}$ and $\mathrm{Fe}$ contents through transported cover and underlying lateritic profile on weathered pyroxenite in drill hole NA68, Site 2.

At both sites, the $\mathrm{pH}$ of the surface soil is generally around 6 but increases to $8-9$ at a depth of $1.5 \mathrm{~m}$. Small calcrete nodules are common in the lower part of the soil at Site 2 . Depth of the water table in the local Miandetta-Hermidale area (observed in 14 air core drill holes) is between 30 and $67 \mathrm{~m}$ [17].

\section{Materials and Methods}

\subsection{Vegetation Sampling and Analysis}

Pine needles were collected from individual mature trees (generally 4-12 $\mathrm{m}$ tall) at different locations across both study sites (Figure 5). Needles were taken at a height of 1.5-2.5 $\mathrm{m}$ around each tree to provide bulk samples of at least $100 \mathrm{~g}$. These were collected by hand using unpowdered latex gloves, then stored in brown paper bags and air dried.

The first round of sampling was conducted in late January (summer) 2006 during an extended period of drought when it was expected that trees would be drawing on deep water in the regolith. A total of 11 trees were sampled at Site 1 and 11 at Site 2. Some initial reconnaissance sampling of a single tree at Site 1 was conducted in December 2004. 
Pine needles from this test tree (M11, Figure 3) were found to have elevated Ni, and in the 2006 sampling, the pine needles were re-sampled together with samples of the bark, twigs and cones.
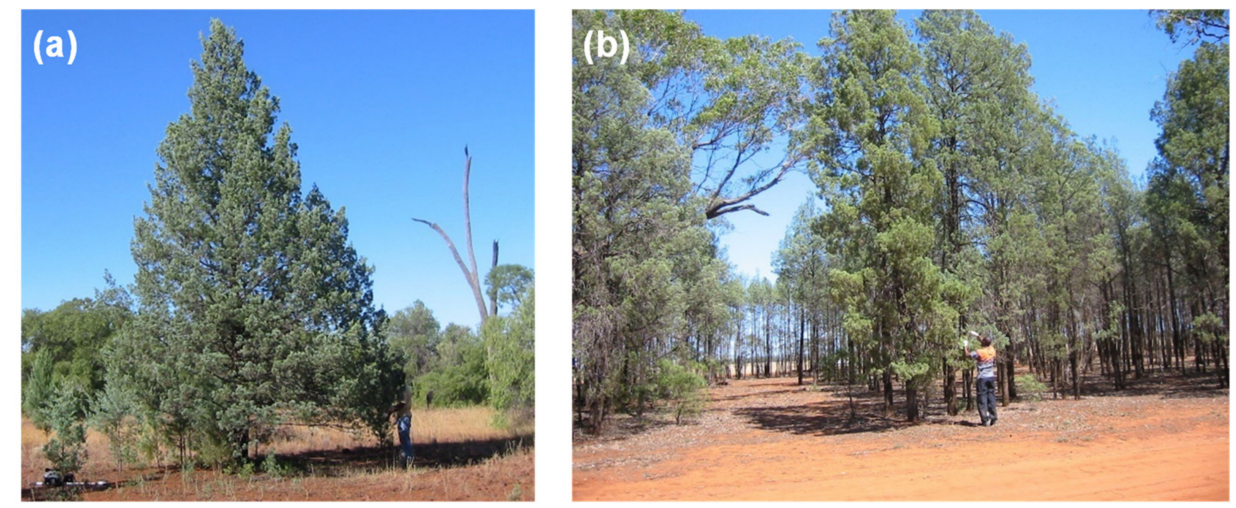

Figure 5. (a) Cypress pine (C. glaucophylla) tree M11 at Site 1. Leaves (needles) from this tree were sampled in December 2004 and January 2006; samples of twigs, cones and bark were taken in January 2006. (b) Windbreak reserve with C. glaucophylla between cleared paddocks at Site 2 also showing surficial cover and sampling method.

Additional pine needles and adjacent soils at 20 of the locations were subsequently collected at Site 1 along Munda Lane as part of a regional biogeochemical mapping program of the Cobar region in late 2020. This was followed by detailed infill sampling across the quarry area in February 2021. Sample sites for this sampling are shown in Figure 6.

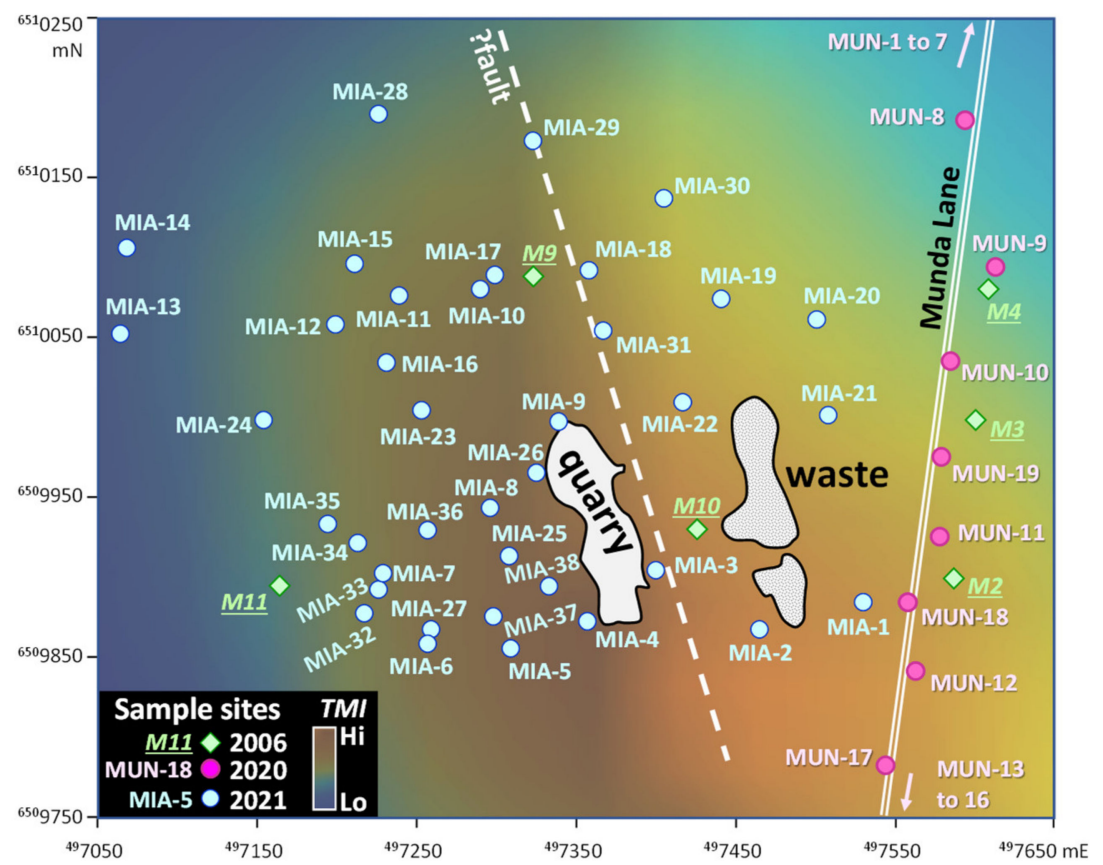

Figure 6. Location of cypress pine trees sampled in 2006, 2020 and 2021 at Site 1 overlain on a colourgraded image of the total magnetic intensity with warm colours showing higher TMI [18].

Prior to analysis, samples in the first round from sites 1 and 2 in 2006 were washed in an ultrasound bath with distilled water, dried at $60^{\circ} \mathrm{C}$ and macerated in a coffee grinder to $<2 \mathrm{~mm}$. Samples of bark, twigs and cones from test tree M11 were processed by the same procedure. Ground samples of $15 \mathrm{~g}$ were submitted for multi-element instrumental neutron activation analysis (INAA) through Genalysis Laboratories (Perth, Australia) using 
method BQ-INAA-1. These samples were analysed for Ag, As, Au, Ba, Br, Cd, Ce, Co, Cr, $\mathrm{Fe}$, Ir, La, Mo, Na, Ni, Rb, Sb, Sc, Se, Sm, Ta, Th, U, W and Zn. A second subsample of $15 \mathrm{~g}$ was digested in nitric acid and analysed by inductively-coupled optical emission/mass spectrometry (ICP OES/MS) by the same laboratory using method BVeg/OES. This method was used for elements not analysed by INAA $(\mathrm{Cu}, \mathrm{K}, \mathrm{Mg}, \mathrm{Mn}$ and $\mathrm{P})$ and as a cross check on the common elements, particularly $\mathrm{Ni}$. The suite of elements analysed included $\mathrm{Al}, \mathrm{B}$, $\mathrm{Ca}, \mathrm{Cu}, \mathrm{Fe}, \mathrm{K}, \mathrm{Mg}, \mathrm{Mn}, \mathrm{Na}, \mathrm{Ni}, \mathrm{P}, \mathrm{S}, \mathrm{Ti}, \mathrm{V}$ and $\mathrm{Zn}$.

Pine needle samples collected in the 2020-2021 round of sampling were not washed, given recent prior rain events and the lack of observed dust on the needle surfaces, as well as some comparative studies on unwashed and washed samples that showed little systematic difference in trace element concentrations. The samples were dried at $100{ }^{\circ} \mathrm{C}$ and then milled and analysed at LabWest, Perth, using method MSA-06 in which $1 \mathrm{~g}$ of the milled sample was digested in a small amount of aqua regia in a sealed Teflon container in a microwave and analysed by ICP-MS.

As part of the 2020 sampling, needles were also analysed with a Vanta pXRF by positioning the device directly onto the slightly compressed needles in a paper bag. The minimum compressed thickness of the samples was $5 \mathrm{~cm}$, to be beyond the depth of penetration of the X-rays [17]. Multielement analysis was performed in 'Geochem (3beam)' mode with $30 \mathrm{~s}$ counts on each of the three beam configurations. The samples were subsequently milled and re-analysed by pXRF in the laboratory using published methods [19].

\subsection{Soil and Regolith Sampling and Analysis}

Exploration drilling programs at both sites provided soil and regolith samples to assess the bedrock and overlying regolith, including the mineralogy and chemical composition. A total of 112 soil samples were collected at Site 1 on a $500 \mathrm{~m} \times 1000 \mathrm{~m}$ grid at a sample spacing of $50 \mathrm{~m}$ along $100 \mathrm{~m}$ spaced north-south sample lines. These samples were collected at the top of the B horizon (50-70 cm depth). After logging the $1 \mathrm{~m}$ intervals of bulk auger/auger material, a $1 \mathrm{~kg}$ sample was collected using a sampling spear and submitted to ALS-Chemex Laboratories in Brisbane for pulverising, homogenisation and multi element analysis by ICP-OES following digestion by aqua-regia (method ME-ICP44). A contoured plot of the Ni results for this data over Site 1 is shown in Figure 7. The total data set is included in the Supplementary Materials Data. Regolith and soil samples collected at Site 2 from three drill holes (Figure 3) were processed and analysed by the same procedures outlined above.
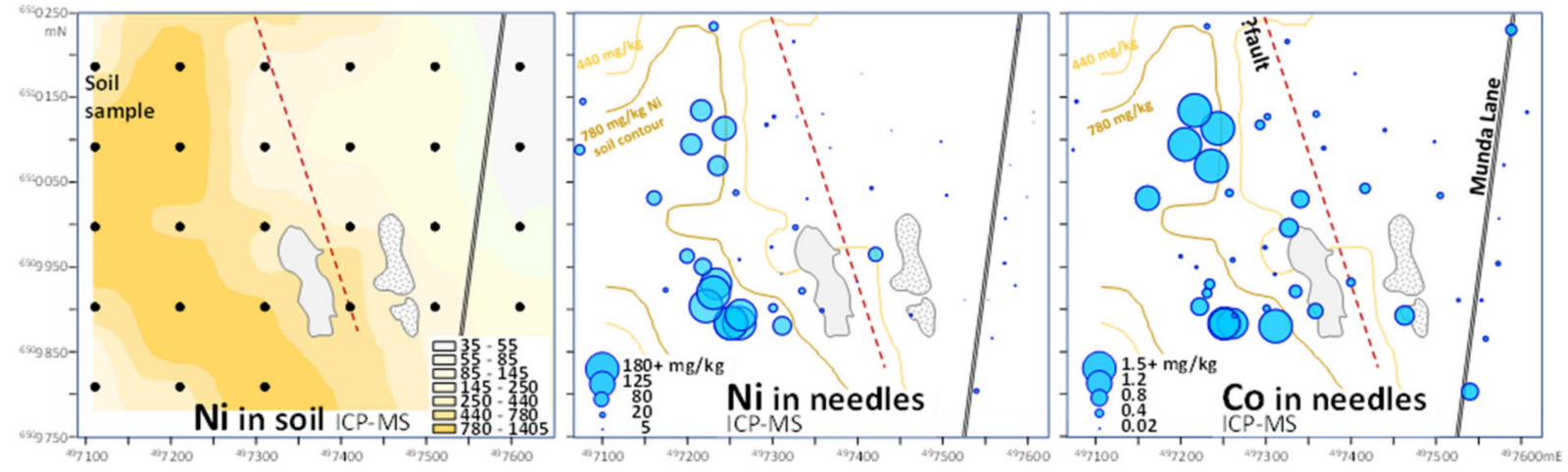

Figure 7. Spatial variation in the concentration of $\mathrm{Ni}$ in $50-70 \mathrm{~cm}$ deep soils, and $\mathrm{Ni}$ and Co in C. glaucophylla needles determined by ICP-MS following a microwave-assisted aqua regia digestion measured in the detailed sampling at Site 1 in 2021.

Although aqua regia is a partial extraction, it digests the common mineral hosts for $\mathrm{Ni}$ in strongly weathered materials (including $\mathrm{Fe}^{\mathrm{III}}$-Mn oxyhydroxides). A set of four soil samples was collected by hand auger from 25 to $70 \mathrm{~cm}$ depth from areas with thin regolith 
cover (see Figure 2 for locations). These $1 \mathrm{~kg}$ samples were subdivided with a riffle splitter and a $200 \mathrm{~g}$ sub-sample was dried at $80^{\circ} \mathrm{C}$ before pulverisation and homogenisation in a zirconia ring mill. A $2 \mathrm{~g}$ sample of this pulverised material was used by ALS-Chemex for sequential extraction and analysis following the $\mathrm{BCR}$ procedure using (i) $0.11 \mathrm{M}$ acetic acid for exchangeable and carbonate-hosted metals, (ii) $0.5 \mathrm{M}$ hydroxyl ammonium chloride in $2 \mathrm{M}$ nitric acid for metal bound in weakly crystalline Fe-Mn oxyhydroxides and (iii) 8.8 M hydrogen peroxide to extract oxidisable or organic-hosted metals [20]. A split of each sample was also digested by aqua-regia.

During the second round of pine needle sampling in 2021, 32 soils were also collected from $0-10 \mathrm{~cm}$ depth adjacent to the trunk of a number of trees, subsequently dried at $110{ }^{\circ} \mathrm{C}$ and sieved to $<2 \mathrm{~mm}$. These sieved samples from the second round were placed in $50 \mu \mathrm{m}$ thick Ziplock bags in the laboratory and analysed by Vanta pXRF in the test stand using the same mode and settings as for the vegetation.

\subsection{Data Analysis and Quality Control}

Data analysis was performed using standard functions in Excel and ArcGIS version 10.4.1.

Quality control was monitored using solution standards and reference materials, including a series of soil and natural organic-rich reference material, as well as a series of synthetic organic-rich reference materials developed as part of a study on the calibration of the pXRF used in this study for the analysis of mineral matter in coal [21], and sub-sample duplicates. Geochemical data and summary statistics for the needle geochemical data and quality control information relating to accuracy and precision of the analyses are presented in the Supplementary Materials. Some elements reported values for most samples below detection limits and were excluded from further assessment.

\section{Results}

The needles of $C$. glaucophylla trees growing directly on the weathered ultramafic profile, including Ni-enriched laterite, at Site 1 contained up to $180 \mathrm{mg} / \mathrm{kg}$ dry-weight $\mathrm{Ni}$ (Figures 2 and 7). Peak Ni values were in two stands of trees, the first just west of the quarry in an area of skeletal transported regolith cover and another similar zone $50 \mathrm{~m}$ to the north. At Site 2, the Ni contents of the sampled needles ranges from $2-5 \mathrm{mg} / \mathrm{kg}$ (mean $3.4 \mathrm{mg} / \mathrm{kg}$ ). Data (unpublished) from the biogeochemical mapping of the Cobar Basin, where the dominant rock types are silicic sediments and intermediate to felsic igneous units, indicate regional backgrounds of $<3 \mathrm{mg} / \mathrm{kg} \mathrm{Ni}$. The main population breaks were determined by examination of both quantile-quantile and number-size fractal plots [22]. There were clear population breaks in the $\mathrm{Ni}$ and Co data at 3,20 and $180 \mathrm{mg} / \mathrm{kg} \mathrm{Ni}$, as well as 0.2 and $1.4 \mathrm{mg} / \mathrm{kg}$ Co (Figure 8 ).
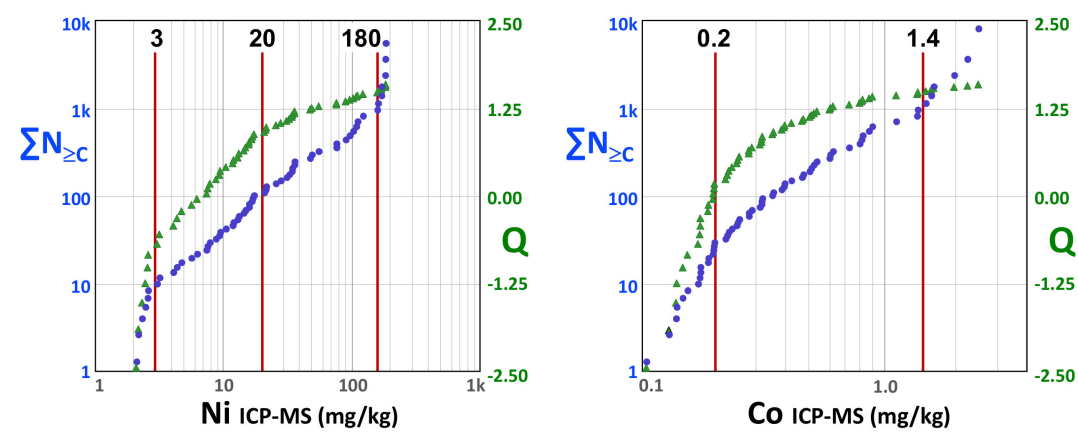

Figure 8. Identification of population boundaries in the $\mathrm{Ni}$ and Co content of C. glaucophylla needles for the combined Site 1 and Site 2 data using quantile-quantile plots (blue circles) number concentration fractals (green triangles).

The soils at Site 1 displayed Ni values in the range $360-2060 \mathrm{mg} / \mathrm{kg}$ and the underlying saprolite up to $2100 \mathrm{mg} / \mathrm{kg}$ Ni. Concentrations were much lower at Site 2 where the 
dominantly transported regolith contains $17-325 \mathrm{mg} / \mathrm{kg} \mathrm{Ni}$ and the underlying saprolite profile, $1000-3700 \mathrm{mg} / \mathrm{kg}$ Ni. The sequential extraction analysis of soils at Site 1 indicated that only a very small proportion $(<2 \%$ of the total metal content) of the minor and trace cations in the soil $(<1 \mathrm{~m}$ deep) were present in readily available forms such as exchangeable sites on minerals, carbonates, poorly crystalline Fe-Mn oxyhydroxides or soil organics. In the case of $\mathrm{Ni}$, it was $<0.1 \%$ of the total Ni content of the soil (see analyses in Supplementary Materials). At Site 2, the Ni content of the soils and regolith to a depth of $15 \mathrm{~m}$ was less than $250 \mathrm{mg} / \mathrm{kg}$.

Where element values exceeded regional background thresholds, Ni displayed the strongest correlation between needles and adjacent soils, as well as between ICP-MS on milled samples and in situ analysis by pXRF (Figures 9 and 10). There was little correlation between the needles and soils for $\mathrm{Fe}$ or $\mathrm{Cu}$, although these elements displayed very limited relative variation across the sites (Supplementary Materials Figures S1 and S2).
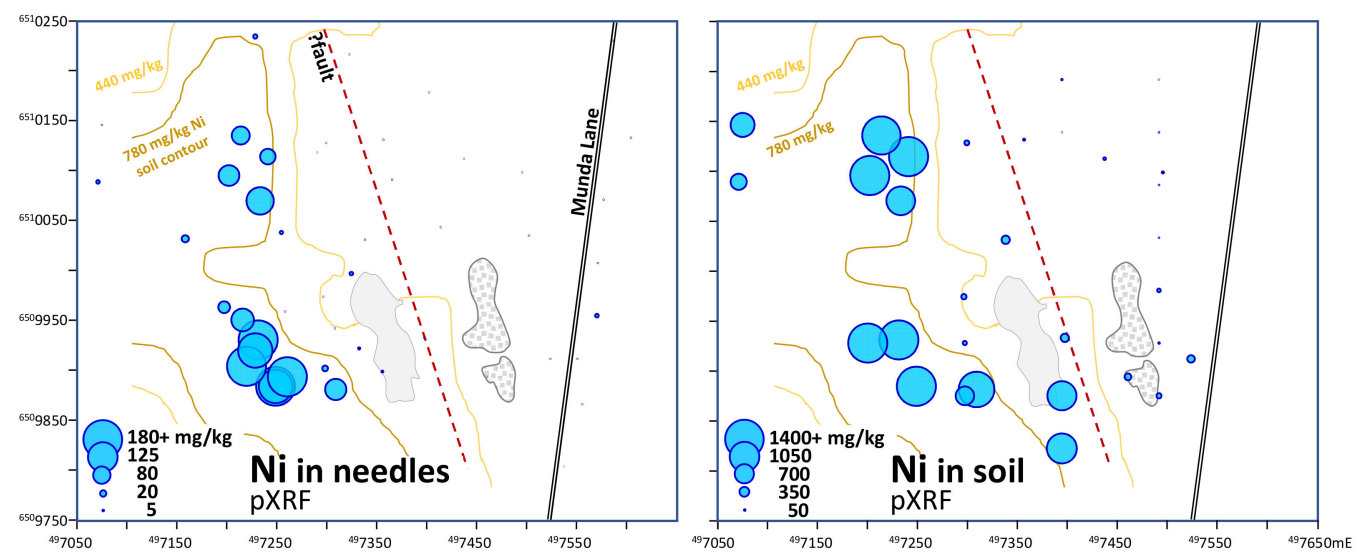

Figure 9. Spatial variation in the Ni content of C. glaucophylla needles and top $10 \mathrm{~cm}$ of soil (by pXRF) at Site 1, with 780 and $440 \mathrm{mg} / \mathrm{kg}$ Ni soil grid contours from [15].
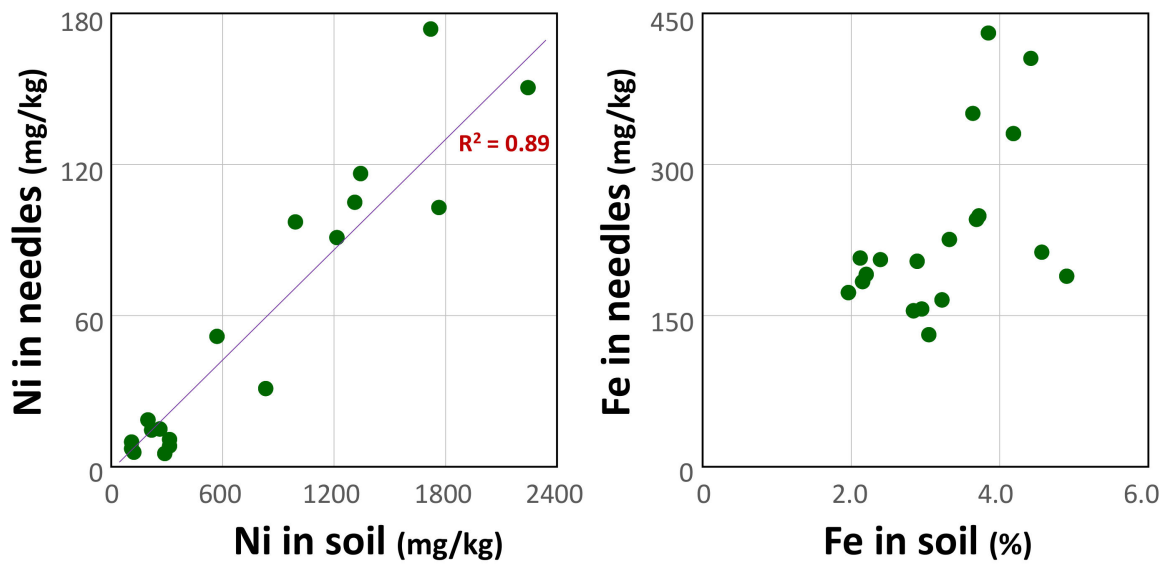

Figure 10. Scatter plots of $\mathrm{Ni}$ and Fe in C. glaucophylla needles versus adjacent soils at Site 1.

The relationship between the Ni content of pine needles and the thickness and type of regolith is shown in Figure 11. In areas with a mix of colluvium and alluvium $<5 \mathrm{~m}$ thick (Site 1), Ni values ranged from $5-80 \mathrm{mg} / \mathrm{kg}$. For trees growing over ultramafic units but with transported regolith cover of 10-50 $\mathrm{m}$ thickness (Site 2), values did not exceed $5 \mathrm{mg} / \mathrm{kg} \mathrm{Ni}$ (Figure 11). 


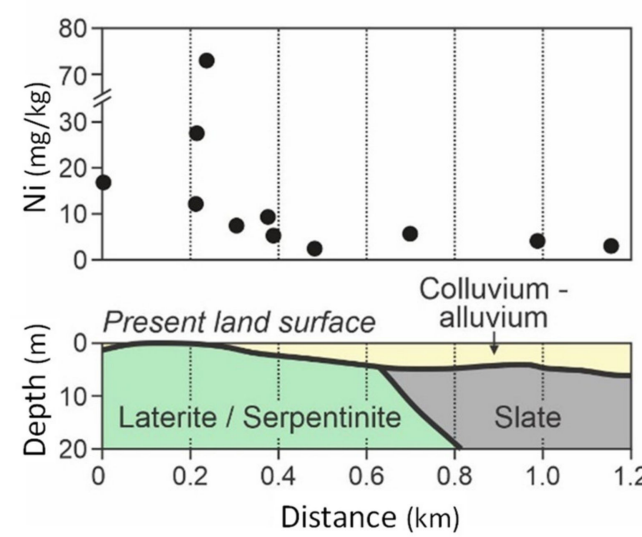

(a)

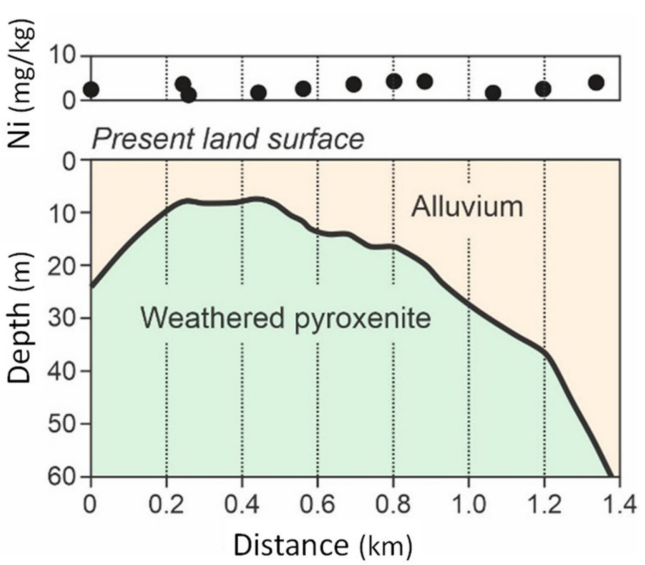

(b)

Figure 11. Plot of Ni content of pine needles versus depth to weathered Ni-rich ultramafic rocks, saprolite and laterite through (a) colluvium and alluvium at Site 1 and (b) transported alluvial regolith at Site 2.

For the ICP analyses of needles, Fe is highly correlated with $\mathrm{Al}$, though the trends for the two sites are different, with higher Fe in the needles at Site 2 (Figure 12). The pattern for $\mathrm{Na}$ is similar, though the correlation is weaker, and both $\mathrm{Ni}$ and $\mathrm{Ca}$ are uncorrelated with Al. Most other trace elements analysed, including $\mathrm{Cu}, \mathrm{Mn}$ and $\mathrm{Zn}$, did not display any systematic relationship to regolith type or thickness.
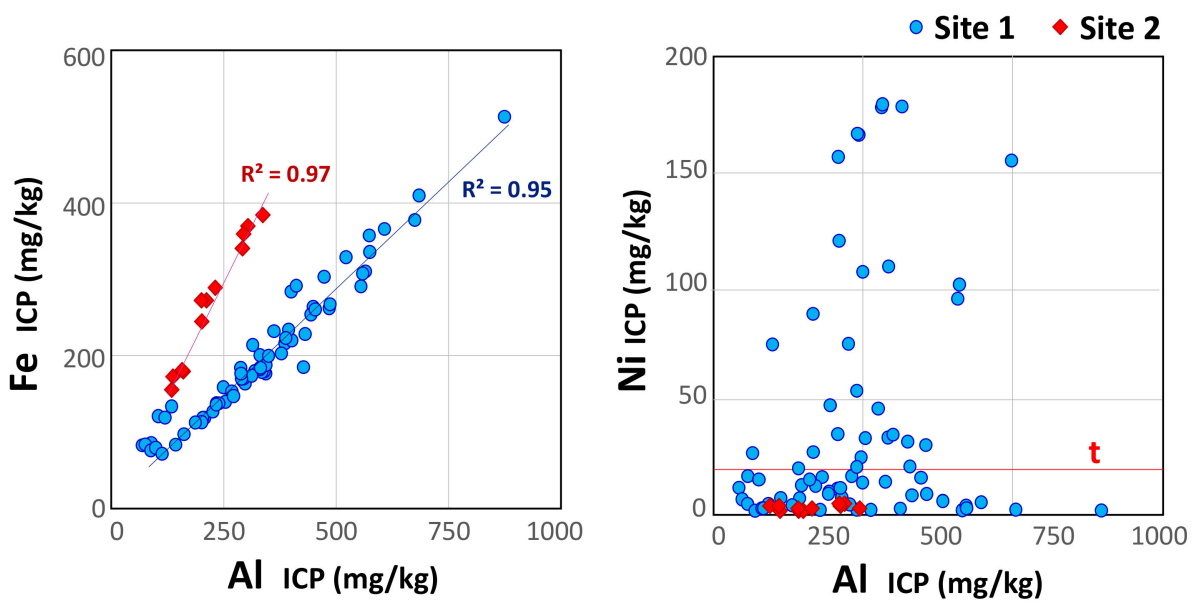

Figure 12. Scatter plots of Fe and Ni in C. glaucophylla needles at Sites 1 and 2. The Ni threshold (t) corresponds with the second break shown in Figure 8.

The results for different organs from the single tree sampled indicated $\mathrm{Ni}$ to be highest in the cones followed by the needles (Supplementary Materials Figure S3). This was similar for other micronutrients, though $\mathrm{Zn}$ was higher in the needles. The bark has a very high Fe content $(1000 \mathrm{mg} / \mathrm{kg})$, possibly an indicator of dust contamination in the rough and porous material.

A comparison between the pXRF, INAA and ICP-OES/MS analysis of sub-samples from the same bulk samples of needles show positive correlation for Ni (Figure 13) once values exceed the detection limits ( $5 \mathrm{mg} / \mathrm{kg}$ for $\mathrm{pXRF}$ and INAA and $0.1 \mathrm{mg} / \mathrm{kg}$ of ICP). There is overestimation of $\mathrm{Ni}$ in the pXRF data (Figure 13a), but with a strong linear relationship, the data can be adjusted to allow ICP and pXRF data to be merged. 


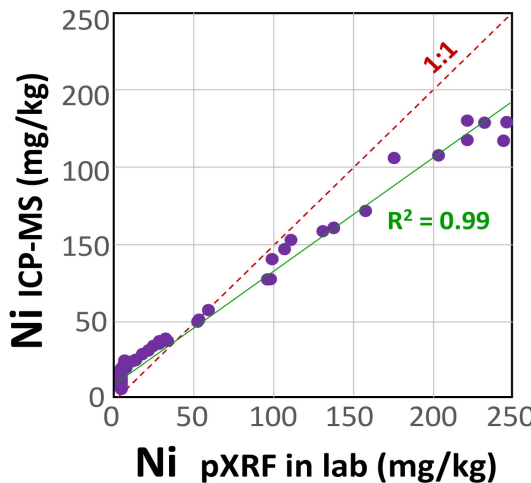

(a)

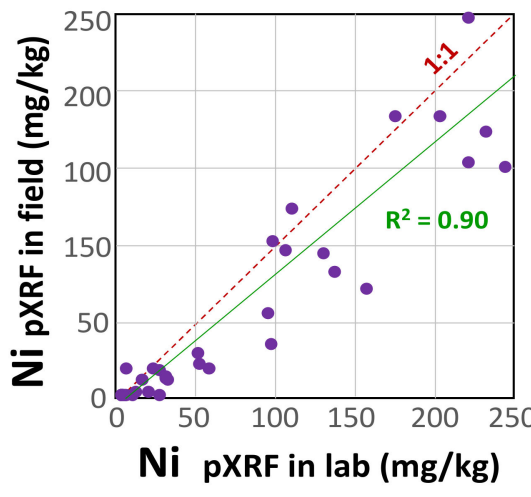

(b)

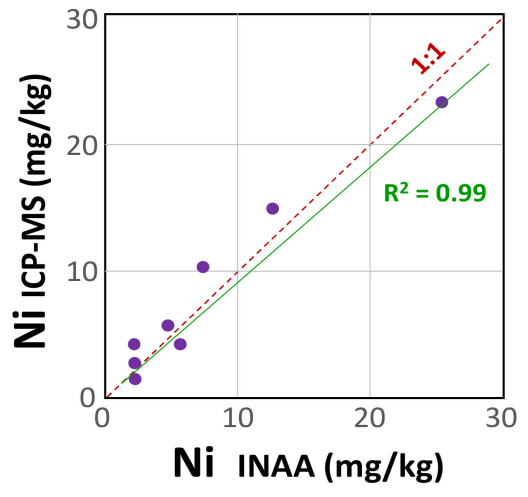

(c)

Figure 13. Comparison between analyses of $\mathrm{Ni}$ in C. glaucophylla needles with the 1:1 line and linear correlation shown for (a) pXRF in the lab on milled samples versus ICP-MS, (b) pXRF in the lab on milled samples versus direct analysis on unprocessed samples in the field and (c) ICP-MS versus INAA on milled samples.

\section{Discussion}

Elevated levels of $\mathrm{Ni}$ in C. glaucophylla needles have not been reported previously. This study has shown that the needles of such pine trees growing in a Ni-rich substrate at Site 1 have accumulated up to two orders of magnitude higher Ni than typical regional values observed over felsic igneous and siliceous sediments elsewhere in the Cobar region. This typical background of $2-3 \mathrm{mg} / \mathrm{kg}$ Ni observed elsewhere presumably reflects the $\mathrm{Ni}$ micronutrient requirements of this species. The subsequent re-sampling program showed that these elevated levels of $\mathrm{Ni}$ are maintained over time, at least for 15 years, and are largely unaffected by variations in rainfall immediately prior to sampling.

Comparing results from the two sites, it is possible to estimate the depth to which white cypress pines can extract $\mathrm{Ni}$ from the regolith in areas with transported cover. At Site 1, the trees have accumulated higher levels of $\mathrm{Ni}$ in regolith cover, which includes residual weathering profiles over ultramafic rocks and transported colluvium, to a depth of at least $3 \mathrm{~m}$. However, at Site 2, where the transported cover is greater than $10 \mathrm{~m}$ thick, high $\mathrm{Ni}$ concentrations in the underlying, buried weathering profile are not expressed in the pine needles. The findings assist in understanding the limits on the depth to which C glaucophylla can detect anomalous levels of $\mathrm{Ni}$ and other transition elements through transported cover. This highlights the importance of understanding and delineating the nature of regolith cover before undertaking biogeochemical surveys, particularly in deeply weathered, polygenetic landscapes.

The sequential extraction results for soil at Miandetta show very low levels of readily accessible Ni, Co, V, Mn and other trace elements, despite high total abundance. This is consistent with long-term, near-surface weathering and oxidation, but with retention of these elements in well-crystalline Fe (hydr)oxides. The uptake of $\mathrm{Ni}$ in C. glaucophylla may be occurring deeper in the regolith, possibly near the weathering front in the underlying Ni-rich ultramafic rocks. However, given the apparent shallow depth penetration of the cypress pine root system, it is probably more likely that biochemical processes in the microbiome of the rhizosphere are facilitating uptake of metals that are otherwise strongly bound within secondary Fe minerals [23], although there has been little detailed investigation of the biogeochemical pathways for C. glaucophylla.

Many transition elements, including $\mathrm{Fe}, \mathrm{Mn}, \mathrm{Co}, \mathrm{Cu}, \mathrm{Mo}, \mathrm{Ni}$ and $\mathrm{Zn}$, are essential micronutrients for most plants when present in appropriate trace amounts [24]. In high concentrations, these elements can also be toxic, and hence plants have mechanisms for controlling the uptake levels of elements to obtain the required level of micronutrients and avoid the toxic effects of very high levels [25]. Uptake of metals into the vascular system of plants requires the metals to either be in soluble form or solubilised in the rhizosphere by root exudates or microbiotic interaction [26]. Bacterial activity in the rhizosphere can locally 
acidify the soil, allowing increased solubility of transition elements, including increased solubility of ferric iron complexes.

As a micronutrient, $\mathrm{Ni}$ is important for the formation of several metallo-enzymes in higher order plants, including urease, Ni-Fe hydrogenase and Ni-superoxide dismutase [27,28]. Urease can hydrolyse urea to ammonia, preventing toxic build-up and assisting the formation of N-based molecules such as amino acids in plants [29]. Nickel may also be involved in the synthesis of metabolites that contribute to plant resistance against various stresses [30]. Excess $\mathrm{Ni}$ can have a range of deleterious effects such as reduced uptake of Fe and other nutrients or substitution and competition for Co and other divalent ions [31] with consequences for metabolic processes that require those elements [32,33]. Various studies on pines indicate high resistance to effects (and barriers to uptake) from high $\mathrm{Cu}$ in the substrate [34] and much greater toxicity effects from other transition metals where there is high Ni uptake [35].

The current study has shown that in C. glaucophylla, Ni uptake can exceed the apparent micronutrient requirement by up to two orders of magnitude without any obvious signs of toxicity, such as stunted growth, or chlorosis and necrosis of the needles [36]. While it is possible that the trees can control the upper limit of Ni uptake to below toxicity, this limit is significantly above the typical $\mathrm{Ni}$ levels found in trees growing in regolith with background or low Ni concentrations $(<200 \mathrm{mg} / \mathrm{kg}$ ). The composition of soils and parent lithologies strongly influence the uptake of most metals unless plants exert barriers. Additionally, plants may alter weathering rates and element mobilities by the range of organic species added to soil profiles due to metabolites exuded from roots or from decaying leaves and the ensuing $\mathrm{pH}$ changes [37,38].

In the case of other micronutrient transition elements such as $\mathrm{Co}, \mathrm{Cu}, \mathrm{Zn}$ and $\mathrm{Mo}$, the range between minimum and maximum tolerable limits is not known. Detailed investigation of the achievable levels of uptake and the possibility of homeostasis control of upper limits for these elements is required before C. glaucophylla needles can be considered a suitable sampling medium for biogeochemical exploration of these other micronutrient elements. At both study sites, the level of $\mathrm{Cu}$ in needles is consistently between $2-5 \mathrm{mg} / \mathrm{kg}$, suggesting that $C$. glaucophylla may have a tight upper limit control on $\mathrm{Cu}$ uptake, although the maximum concentration for $\mathrm{Cu}$ found in the soil was only $227 \mathrm{mg} / \mathrm{kg}$ (at Site 1) and generally below $60 \mathrm{mg} / \mathrm{kg}$.

The contents of some major elements in the C. glaucophylla needles show interesting differences between the two different study sites. These differences could reflect the nature and composition of the underlying regolith and the form in which some elements are held in the soil at the two sites. Higher concentrations of $\mathrm{Al}, \mathrm{Fe}$ and $\mathrm{Na}$ at Site 2 could be due to more abundant clay and the more sodic (saline) nature of the transported regolith. Iron and $\mathrm{Al}$ show strong positive correlation at both sites (Figure 8) and Na and Al show moderate positive correlation. At Site 1, the Fe content of needles is lower for the trees growing on the iron-rich substrate of laterite and serpentinite. This marked difference in iron content could be due to the iron being present in a less available form here compared to Site 2 (e.g., a much greater abundance of strongly bound $\mathrm{Fe}^{3+}$ relative to $\mathrm{Fe}^{2+}$ ). It is also possible that a superabundance of $\mathrm{Fe}^{3+}$ has either overwhelmed the normal biotic processes for reduction of $\mathrm{Fe}^{3+}$ to $\mathrm{Fe}^{2+}$ or induced the trees in this environment to more effectively control $\mathrm{Fe}^{2+}$ uptake [28].

\section{Conclusions}

This study has demonstrated that highly elevated concentrations of $\mathrm{Ni}$ can accumulate in the needles of white cypress pine (C. glaucophylla) growing in Ni-enriched regolith on weathered ultramafic rocks. The anomalous concentrations are persistent over multiple growing seasons. As a widespread species in semi-arid areas of Australia, C. glaucophylla has potential in reconnaissance biogeochemical exploration over terrain where the target elements have been hydro-morphically or mechanically dispersed to within $3 \mathrm{~m}$ of surface. Due to its extensive near-surface root system (to a radius of $6 \mathrm{~m}$ ), the species should 
accumulate elements from a larger sample of the shallow regolith (down to at least $2 \mathrm{~m}$ ), providing potential advantages over singe point soil samples.

Wider use of C. glaucophylla in biogeochemical exploration requires improved knowledge of the specific mechanisms of metal uptake and controls of homeostasis in the species for a wider range of target elements. This is necessary to establish factors controlling variation in background (normal micronutrient requirements) and the extent to which the species can control or limit the uptake of target elements.

In situ analysis of needles by pXRF has delivered very similar results to ICP-MS for $\mathrm{Ni}$ and other transition metals associated with ultramafic lithologies, opening up the possibility of using $\mathrm{pXRF}$ as the principal biogeochemical analytical method in exploration for Ni mineralisation, with the advantage of the acquisition of data in the field.

The study also highlights the importance of understanding the nature of the regolith and the need for regolith-landform mapping to provide a context for biogeochemical exploration in the Australian landscape, both for planning surveys and interpretation of results. Of particular importance is the recognition and differentiation of in situ and significantly transported regolith.

Supplementary Materials: The following are available online at https://www.mdpi.com/article/ $10.3390 / \min 11080808 / \mathrm{s} 1$, Table S1: Summary of analytical methods, Figure S1: Spatial variation in the Ni content of C. glaucophylla needles and top $20 \mathrm{~cm}$ of soil (by pXRF) at Site 1, Figure S2: Spatial variation in the $\mathrm{Si}$ and $\mathrm{Cr}$ content of $\mathrm{C}$. glaucophylla needles (by pXRF) at Site 1, Figure S3: Comparison between the $\mathrm{Fe}, \mathrm{Ni}, \mathrm{Cr}$ and $\mathrm{Zn}$ content of the needles, cones, twigs and bark of C. glaucophylla tree M1, Table S2: Summary statistics for C. glaucophylla samples from Sites 1 and 2, Figure S4: Comparison between $\mathrm{PXRF}$ and other analytical methods for certified and in-house soil reference materials, Figure S5: Comparison between $\mathrm{pXRF}$ and laboratory $\mathrm{XRF}$ for series of coal-based synthetic geochemical reference materials [21], Figure S6: Plot of analytical duplicates of needle samples by pXRF and ICP-MS for selected elements. File S1: Excel files of biogeochemical data: 1. ICP-OES, INAA, ICP-MS and pXRF analyses of C. glaucophylla needles; 2 . Sequential soil analyses.

Author Contributions: Conceptualization, K.G.M.; methodology, K.G.M., J.A.S., A.A. and D.R.C.; software, D.R.C. and J.A.S.; validation, K.G.M., D.R.C. and J.A.S.; formal analysis, K.G.M., A.A., J.A.S. and D.R.C.; investigation, K.G.M., A.A. and J.A.S.; resources, K.G.M., A.A. and J.A.S.; data curation, K.G.M. and D.R.C.; writing—original draft preparation, A.A., J.A.S., K.G.M. and D.R.C.; writingreview and editing, J.A.S., K.G.M. and D.R.C.; visualization, K.G.M. and D.R.C.; supervision, K.G.M. and D.R.C.; funding acquisition, K.G.M. and J.A.S. All authors have read and agreed to the published version of the manuscript.

Funding: The sampling and biogeochemical analysis reported in this study were supported by funding from the Australian Government's Cooperative Research Centre Program, within the CRC for Landscape, Environment and Mineral Exploration and subsequently the MinEx CRC. J.A.S. is supported by a scholarship from the MinEx CRC and a UNSW RTS scholarship.

Data Availability Statement: The data presented in this study are provided in the Supplementary Materials.

Acknowledgments: The work has been supported by the Mineral Exploration Cooperative Research Centre whose activities are funded by the Australian Government's Cooperative Research Centre Program. Jervois Mining Limited provided access to their lease areas at Miandetta (Site 1) and Gilgai (Site 2) as well as access to their soil sampling and drill hole data. Anthony Jannick of Jervois Mining is particularly thanked for his assistance. The former and current landowners at Miandetta facilitated access to their properties. The article has been improved by the helpful comments and suggestions of three anonymous reviewers and the guest editor.

Conflicts of Interest: There are no conflict of interest. 


\section{References}

1. Arne, D.; Stott, J.; Waldron, H. Biogeochemistry of the Ballarat East goldfield, Victoria, Australia. J. Geochem. Explor. 1999, 67, 1-14. [CrossRef]

2. Hulme, K.A.; Dunn, C.E.; Hill, S.M. Biogeochemistry for mineral exploration in Canada \& Australia: A comparison based on international collaboration. In Proceedings of the Regolith 2006: Consolidation and Dispersion of Ideas; Fitzpatrick, R.W., Shand, P., Eds.; CRC LEME: Perth, WA, USA, 2006; pp. 161-165.

3. Dunn, C.E. Biogeochemistry in Mineral Exploration. In Handbook of Exploration and Environmental Geochemistry Volume 9; Elsevier: Amsterdam, The Netherlands, 2007; 480p.

4. Dunn, C.E. New perspectives on biogeochemical exploration. In Proceedings of the Exploration ‘07: Fifth Decennial International Conference on Mineral Exploration, Toronto, ON, Canada, 9-12 September 2007; Milkereit, B., Ed.; Decennial Mineral Exploration Conferences 2007. pp. 249-261.

5. Reid, N.; Hill, S. Biogeochemical sampling for mineral exploration in arid terrains: Tanami Gold Province, Australia. J. Geochem. Explor. 2010, 104, 105-117. [CrossRef]

6. Anand, R.; Cornelius, M.; Phang, C. Use of vegetation and soil in mineral exploration in areas of transported overburden, Yilgarn Craton, Western Australia: A contribution towards understanding metal transportation processes. Geochem. Explor. Environ. Anal. 2007, 7, 267-288. [CrossRef]

7. Reid, N.; Hill, S.M.; Lewis, D. Spinifex biogeochemical expressions of buried gold mineralisation: The great mineral exploration penetrator of transported regolith. Appl. Geochem. 2008, 23, 76-84. [CrossRef]

8. Lacey, C.J. Silvicultural Characteristics of White Cypress Pine; Research Note No. 26; Forestry Commission of N.S.W.: Sydney, Australia, 1973; 51p.

9. Johnston, T.N. Thinning Studies in Cypress Pine in Queensland; Research Paper No. 7; The Queensland Department of Forestry: Queensland, Australia, 1975; 83p.

10. Thompson, W.A.; Eldridge, D.J. White cypress pine (Callitris glaucophylla): A review of its roles in landscape and ecological processes in eastern Australia. Aust. J. Bot. 2005, 53, 555-570. [CrossRef]

11. Eberbach, P.L. The eco-hydrology of partly cleared, native ecosystems in southern Australia: A review. Plant Soil 2003, 257, 357-369. [CrossRef]

12. Burrows, W.H.; Hoffman MBCompton, J.F.; Back, P.V. Allometric Relationships and Community Biomass Stocks in White Cypress Pine (Callitris glaucophylla) and Associated Eucalypts of the Carnarvon Area-South Central Queensland; National Carbon Accounting System Technical Report No. 33; Australian Greenhouse Office: Canberra, Australia, 2001; 16p.

13. Cohen, D.; Shen, X.; Dunlop, A.; Rutherford, N. A comparison of selective extraction soil geochemistry and biogeochemistry in the Cobar area, New South Wales. J. Geochem. Explor. 1998, 61, 173-189. [CrossRef]

14. Jervois Mining Ltd. Third Annual Exploration Report on ELs 6009, 6095 E 6096, Nyngan Area; Report R000548151 GS2005/582; Geological Survey of NSW: Maitland, NSW, Australia, 2005; 18p.

15. Alpine Meadows Clean Fill Pty Ltd. Second Annual Exploration Report on EL8285-Miandetta Project; Report RE0008680 GS2016/0943; Geological Survey of NSW: Maitland, NSW, Australia, 2016; 14p.

16. Richardson, R. Final Report for EL 2654 (Miandetta), Nyngan, NSW; For Platinum Search NL; Report R00001782 GS1991/209; Geological Survey of NSW: Maitland, NSW, Australia, 1993; 13p.

17. Chan, R.A.; Greene, R.S.B.; Hicks, M.; Maly, B.E.R.; McQueen, K.G.; Scott, K.G.M. Regolith Architecture and Geochemistry of the Hermidale Area of the Girilambone Region, North-Western Lachlan Fold Belt, NSW; CRC LEME Open File Rpt: Bentley, WA, USA, 2002; Volume 149, 48p.

18. Minview Portal Geological Survey of NSW. Available online: https:/ / minview.geoscience.nsw.gov.au/ (accessed on 18 April 2021).

19. Rincheval, M.; Cohen, D.R.; Hemmings, F.A. Biogeochemical mapping of metal contamination from mine tailings using fieldportable XRF. Sci. Total Environ. 2019, 662, 404-413. [CrossRef] [PubMed]

20. Rauret, G.; López-Sánchez, J.F.; Sahuquillo, A.; Rubio, R.; Davidson, C.; Ure, A.; Quevauviller, P. Improvement of the BCR three step sequential extraction procedure prior to the certification of new sediment and soil reference materials. J. Environ. Monit. 1999, 1, 57-61. [CrossRef] [PubMed]

21. Ward, C.R.; Kelloway, S.J.; Vohra, J.; French, D.; Cohen, D.R.; Marjo, C.; Wainwright, I.E. In-situ inorganic analysis of coal seams using a hand-held field-portable XRF Analyser. Int. J. Coal Geol. 2018, 191, 172-188. [CrossRef]

22. Yilmaz, H.; Cohen, D.R.; Sonmez, F.N. Comparison between the effectiveness of regional BLEG and -80\# stream sediment geochemistry in detection of precious and base metal mineral deposits in Western Turkey. J. Geochem. Explor. 2017, 181, 69-80. [CrossRef]

23. Field, J.; Little, D. Regolith and biota. In Regolith Science; Scott, K.G.M., Pain, C.F., Eds.; CSIRO Publishing: Collingwood, VIC, Australia, 2008; pp. 175-217.

24. Alloway, B.J. Heavy Metals and Metalloids as Micronutrients for Plants and Animals. In Climate Change Impacts on Water Resources; Springer Science and Business Media LLC: Berlin/Heidelberg, Germany, 2013; pp. 195-209.

25. Krämer, U.; Talke, I.N.; Hanikenne, M. Transition metal transport. FEBS Lett. 2007, 581, 2263-2272. [CrossRef]

26. Gonzalez-Guerrero, M.; Escudero, V.; Saez, A.; Tejada-Jiménez, M. Transition Metal Transport in Plants and Associated Endosymbionts: Arbuscular Mycorrhizal Fungi and Rhizobia. Front. Plant Sci. 2016, 7, 1088. [CrossRef] [PubMed] 
27. Brown, P.H.; Welch, R.M.; Cary, E.E. Nickel: A Micronutrient Essential for Higher Plants. Plant Physiol. 1987, 85, 801-803. [CrossRef] [PubMed]

28. Abou Seeda, M.A.; EL-Sayed, A.A.; Yassen, A.A.; Abou El-Nour, E.A.A.; Zaghloul, S.M.; Gad Mervat, M. Nickel, Iron and Their Diverse Role in Plants: A Review, Approaches and Future Prospective. Middle East J. Appl. Sci. 2020, 10, 196-219. [CrossRef]

29. Fabiano, C.C.; Tezotto, T.; Favarin, J.L.; Polacco, J.C.; Mazzafera, P. Essentiality of nickel in plants: A role in plant stresses. Front. Plant Sci. 2015, 6, 754. [CrossRef] [PubMed]

30. Ahmad, M.S.A.; Ashraf, M. Essential Roles and Hazardous Effects of Nickel in Plants. In Reviews of Environmental Contamination and Toxicology; Springer: New York, NY, USA, 2012; Volume 214, pp. 125-167. [CrossRef]

31. Ahmad, M.S.A.; Hussain, M.; Saddiq, R.; Alvi, A.K. Mungbean: A Nickel Indicator, Accumulator or Excluder? Bull. Environ. Contam. Toxicol. 2007, 78, 319-324. [CrossRef]

32. Wood, B.; Reilly, C.; Nyczepir, A. Field Deficiency of Nickel in Trees: Symptoms and Causes. Acta Hortic. 2006, 721, 83-98. [CrossRef]

33. Kupper, H.; Kroneck, P.M.H. Nickel in the environment and its role in the metabolism of plants and cyanobacteria. In Metal Ions in Life Sciences; Sigel, A., Sigel, H., Sigel, R.K.O., Eds.; Wiley: Hoboken, NJ, USA, 2007; pp. 31-62.

34. Cohen, D.R.; Zissimos, A.M.; Schifano, J.A.; Rutherford, N.F. Biogeochemical response of Pinus brutia and Olea europaea to lithological variations and Cu mineralisation in Cyprus. Sci. Total Environ. 2021, 759, 143434. [CrossRef]

35. Kukkola, E.; Rautio, P.; Huttunen, S. Stress indications in copper- and nickel-exposed Scots pine seedlings. Environ. Exp. Bot. 2000, 43, 197-210. [CrossRef]

36. Yusuf, M.; Fariduddin, Q.; Hayat, S.; Ahmad, A. Nickel: An Overview of Uptake, Essentiality and Toxicity in Plants. Bull. Environ. Contam. Toxicol. 2011, 86, 1-17. [CrossRef] [PubMed]

37. Scholes, M.C.; Nowicki, T. The effects of pines on soil processes and properties. In Ecology and Biogeography of Pinus; Richardson, D.M., Ed.; Longman: London, UK, 1998; pp. 341-353.

38. Payet, C.; Scholes, M.C.; Balkwill, K. Some effects of the cultivation of pine on the chemistry of ultramafic soils. S. Afr. J. Sci. 2001, 97, 603-608. 